\title{
OPTIMIZATION OF TRIETHYLENE GLYCOL (TEG) DEHYDRATION IN A NATURAL GAS PROCESSING PLANT
}

\author{
Nmegbu Chukwuma Godwin Jacob \\ Department of Petroleum Engineering, Rivers State University of Science and Technology, Port Harcourt
}

\begin{abstract}
In optimizing glycol dehydration system for the natural gas processing, several critical parameters that can be varied to achieve specific dew point depression exist. From HYSYS simulation, a gas plant was placed under investigation with the aim of studying the effects of variation in glycol flow rates, number of stages $\left(4,8\right.$ and 12 trays) of the absorber, reboiler temperature ( $180^{\circ} C$, $190^{\circ} \mathrm{C}$ and $200^{\circ} \mathrm{C}$ ) and stripping gas rate on the water content of the gas in a glycol dehydration unit in the Niger Delta. Results show that an increasing reboler temperature above $200{ }^{\circ} \mathrm{C}$ led to the thermal decomposition of glycol and introduction of stripping gas had a significant effect than increasing the reboiler temperature. Also, the design of the TEG system was adequate to achieve a dew point of about $5^{\circ} \mathrm{C}$ at 95bars. This study therefore seeks to proffer solutions for the optimization of the Niger Delta gas plant dehydration process using the HYSYS simulator.
\end{abstract}

Keywords: Dehydration, Glycol, Optimization TEG..

\section{INTRODUCTION}

Natural gas is a combustible mixture of hydrocarbon gases and a vital component of the world's supply of energy. It is one of the cleanest, safest and most useful of all energy sources, formed primarily of methane, ethane, propane, butane and pentane [1]. In Its processing, the presence of water it poses a great problem and vapors of its water content can lead to hydrate formation at low temperatures and high pressures and/or corrosion when it is in contact with hydrogen sulphide $\left(\mathrm{H}_{2} \mathrm{SO}_{4}\right)$ and carbon dioxide $\left(\mathrm{CO}_{2}\right)$ components which are all present in the gas stream [2]. The removal of the water vapor that exists in these natural gases requires a complex treatment consisting of treatments with varying degrees of efficiency involving gas dehydration processes [3]. Glycol dehydration is the most common dehydration process used to attain pipeline sales specifications and field requirements [2], [4]. [5]. For this process, a liquid desiccant dehydrator serves to absorb water vapor from the gas system within the contactor. This desiccant having glycol as its principal agent has the chemical affinity for water, stripping most water content of the travelling gas stream. Regeneration of this glycol occurs in a specialized reboiler designed to vaporize only the water from the solution [6]. For the past few years, the design of glycol plants utilizes the rule-of thumb procedures. The problem of pigging in export plants reveals a significant wall thickness loss up to about $36 \%$ at some points in pipeline systems.[4], [6], [7] Presence of water in these systems in reaction with $\mathrm{CO}_{2}$ can cause corrosion. Routine pigging assessment showed that $4-9 \%$ of the liquid recovered from plant in the Niger Delta spur of the gas transmission system (GTS) as free water. This research is aimed at optimizing gas plant dehydration systems to meet the specified sales of gas-water dew point requirements of $5^{\circ} \mathrm{C}$ at 95 bar.

\section{MATERIALS AND METHODS}

\subsection{The Contacting Unit (HPLT)}

A glycol contactor is divided into two sections, the smaller lower section known as the scrubber section (integral scrubber) and the larger upper section known as the absorber section consisting of a wire mesh mixed extractor and separation of these two trays is done by installing a special section called the Chimney tray. The wet inlet gas stream enters the integral scrubber tangentially through the gas inlet for centrifugal separation of liquid accumulation and then passes through the high capacity, high efficiency mist extractor for extra trapped liquid contents. The gas stream undergoes several processes before it comes in contact with the glycol liquid flowing counter-currently down the column. As the gas passes through the trays water is absorbed by these glycol from the gases until the gases become extremely dehydrated. Incoming glycol from surge tanks is cooled in a heat exchanger before it enters the top of the contactor through the contactor vessel by passing across the trays, stripping more water till it becomes increasingly enriched with water during the counter flow. Operating efficiency of these contactors depends on the gas flow rate, temperature, pressure and also on the lean glycol concentration and its circulation rate.

\subsection{The TEG Regeneration Unit (HTLP)}

This unit is conditioned with removal of dissolved gases, liquid hydrocarbon, solids and water from the glycol. Rich glycol leaves the contactor and reaches the lean-rich glycol heat exchanger to warn the glycol in order to its viscosity and accelerate glycol-liquid-gas separation in the flash drum, proceeding to the cartridge filters solid particles are removed to prevent plugging in heat exchangers foaming, pigging/fouling, cell corrosion and hot spots on the fire tubes downstream of the cartridge filters. The cooled filtered 
glycol solution is routed through shell side of the HE to warm the glycol in order to reduce fuel consumption in the reboiler before entering the Still Column which operates at atmospheric pressure mounted on the reboiler at a fixed point. Glycol flows downward through the still column towards the reboiler contacting hot glycol vapor, water vapor and stripping gas. The temperature control (heater) in the reboiler operates a fuel gas motor valve to maintain the proper temperature in the glycol to reduce potential glycol degradation at about $374{ }^{\circ} \mathrm{F}$ on the condition that TEG decomposes at a temperature of $404^{\circ} \mathrm{F}$. After a series of other glycol purification process, stripping gas is added to the reboiler to provide extra-dry glycol. TEG recovered from the reboiler which also increases glycol concentrations by providing counter-current contact of the glycol and the stripping gas.. hot regenerated glycol passes through a tube from the stripping column to cool thereby increasing its absorption capacity and its tendency to flash in the contactor.

\subsection{Model Formulation Optimum Operation (Design of the Dehydrating Unit)}

The following steps are requisite for the proposed design;

1. Obtain design information.

2. Select an appropriate combination of lean glycol, circulation rate absorber trays or packing balance.

3. Establish the required balance i.e material balance, energy balance.

The maximum and minimum gas flow rates were taken into account, among others are the gas composition and expected water dew point/ water content of the outlet gas. Obtaining the above parameters, the minimum concentration of TEG in the lean solution entering the top of the absorber required to meet outlet gas water specification. The required lean TEG rate needed to pick-up the necessary amount of water from the gas to meet the outlet gas water content specification.

Also, the amount of absorber contact required to produce the necessary equilibrium in the above at any circulation rate will be considered. Other important considerations such as safety, utilities and environmental regulations for discharging stripper overhead are also evaluated.

\subsection{Process Simulation of Gas Plant-X using} HYSYS

This study analyses the results of a plant simulation performed using the HYSYS simulator. This all-purpose simulator incorporates objective oriented programing techniques to provide an objective linking and embedded (OLE) technology responsible for creating a common interactive interface between HYSYS and other applications. Also providing increased functionality framework in integrating a broad range of technologies under a common look and feel. This simulator offers a unique attribute to support the implementation and solution of a wide range of applications in the chemical, petrochemical, oil and gas industry.

\section{RESULTS AND DISCUSSION}

In order to investigate the important design variables, we obtained plots or residual water content versus circulation rates and they were presented. Among the plots made were for common values of such parameters like numbers of trays in the contactor, glycol circulation rate through the contactor, temperature of the recoiled in the regenerator and the amount of stripping gas used.

\subsection{The Effects of Number of Equilibrium Stages in}

\section{the Absorber}

Figure 1 illustrates the effect of the number of equilibrium contact trays on residual water content using a $200^{\circ} \mathrm{C}$ reboiler. Fig 2 presents a similar response comparing the dew point dispersion in place of actual water content. Increasing water content allows the gas to attain equilibrium with the lean circulation rate. Considering a typical glycol circulation rate of approximately 3 galTEG/lb of water removed, fig 1 and 2 illustrates that a 12 tray contactor is virtually in equilibrium with the inlet glycol. For an 8-tray contactor a circulation rate of about $5-6$ gal TEG/lb water could be required to attain equilibrium.

\subsection{Effects of Reboiler on Temperature}

Increasing reboiler temperature to $204^{\circ} \mathrm{C}$ will result in a thermal decomposition of TEG. Even at $200^{\circ} \mathrm{C}$ reboiler, glycol decomposition can occur due to higher film temperature and as such, temperature of about $180^{\circ} \mathrm{C}, 190^{\circ} \mathrm{C}$ and $200^{\circ} \mathrm{C}$ were simulated Fig 3, 4 and 5 illustrates the overhead water content using a fixed number of trays at reboiler temperatures of $180^{\circ} \mathrm{C}, 190^{\circ} \mathrm{C}$ and $200^{\circ} \mathrm{C}$ for 8 or 12 contactor contactor trays, pipeline quality gas containing less than $711 \mathrm{~b}$ water/MMSCF gas could be produced using either the $190^{\circ} \mathrm{C}$ or $200^{\circ} \mathrm{C}$ reboiler temperature. At $190^{\circ} \mathrm{C}$ approximately $4.5 \mathrm{gal} \mathrm{TEG} / \mathrm{lb}$ water circulation would be needed with 8-tray contactor as opposed to approximately 2 gal TEG/lb-water with 12-tray contactor. Similarly, at $200^{\circ} \mathrm{C}$, approximately 3 gal TEG/lb water circulation would be needed with 8 -tray contactor as opposed to $1.5 \mathrm{gal} \mathrm{TEG} / \mathrm{lb}$ water with 12-tray contactor, noting that the deduced results for the gas inlet temperature of $35,36,37,38$ and $39^{\circ} \mathrm{C}$ were also carried out. This gave a temperature differential ( lean glycol temperature - inlet gas temperature) for $3^{\circ} \mathrm{C}$. reboiler temperature influences the overhead water content by changing the purity of the lean glycol. Glycol purity values of $96.0,97.0$ and $98.0 \mathrm{wt} \%$ were obtained at $180^{\circ} \mathrm{C}, 190^{\circ} \mathrm{C}$ and $200^{\circ} \mathrm{C}$ respectively at pressure of about $1 \mathrm{~atm}$.

\subsection{Effects of Stripping Gas}

Applications requiring high dew point depressions will always utilize stripping gas in the regenerator. A low dew point cannot simply be achieved by using the minimum $98 \%$ obtainable with $200^{\circ} \mathrm{C}$ reboiler temperature at atmospheric pressure. These low dew points will require up to $99.99 \mathrm{wt} \%$ glycol in the absorber. Stripping gas poses a much greater effect than just increasing reboiler temperature. For a maximum efficiency, stripping gas must be introduced in a 
short column after the hot glycol is removed in the reboiler. They may be placed directly in the reboiler but high water partial pressures in the vapor phase limits its mass transfer driving force. Fig 6 and Fig 7 illustrates the stripping gas effects on the residual water content and dew point depression of the dry gas. As seen, at a small stripping gas rate of $1 \mathrm{sc} /$ gal circulation rate, dry gas will contain about half the water of the same process without stripping gas. Increasing the stripping gas rate beyond 2 - 3scf/gal will have a minimal impact on the dew point depression.

Table 1 Deduced Values for water content and circulation rates for 4,8 and 12 trays

\begin{tabular}{|l|l|l|l|}
\hline & \multicolumn{2}{|l|}{$\begin{array}{l}\text { Outlet gas water } \\
\text { (lb/MMSCF) }\end{array}$} & \\
\hline $\begin{array}{l}\text { TEG rate(gal/lb } \\
\text { water) }\end{array}$ & $\mathrm{N}=4$ & $\mathrm{~N}=8$ & $\mathrm{~N}=12$ \\
\hline 7.6 & 9.4 & & \\
\hline 7.2 & 9.6 & 5.2 & 5.0 \\
\hline 6 & 10 & 5.2 & 5.0 \\
\hline 5 & 11 & 5.2 & 5.0 \\
\hline 4 & 12 & 5.8 & 5.0 \\
\hline 3 & 14 & 7.0 & 5.0 \\
\hline 2 & 19 & 9.0 & 6.0 \\
\hline 1.5 & 23 & 11.2 & 7.5 \\
\hline 1.25 & & 13 & 9.0 \\
\hline 0.6 & & & 15 \\
\hline
\end{tabular}

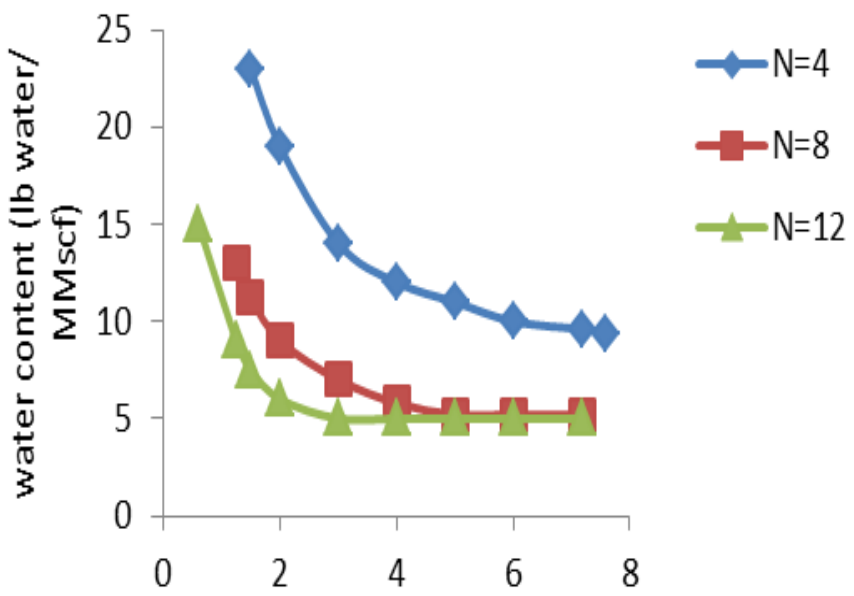

TEG circulation rate (gal/lb-water)

Fig 1 Effects of number of equilibrium stages in the contactor on water content of a stream of natural gas with reboiler temperature of $200^{\circ} \mathrm{C}$
Table 2 Deduced dew point depression for 4, 8 and 12 trays

\begin{tabular}{|l|l|l|l|}
\hline & \multicolumn{3}{|c|}{ Dew point depression $\left({ }^{\circ} \mathrm{C}\right)$} \\
\hline $\begin{array}{l}\text { TEG } \\
\text { rate(gal/lb } \\
\text { water) }\end{array}$ & $\mathrm{N}=4$ & $\mathrm{~N}=8$ & $\mathrm{~N}=12$ \\
\hline 7.6 & 14.444 & & \\
\hline 7.2 & 14.16 & 22.50 & 23.06 \\
\hline 6 & 13.33 & 522.10 & 23.06 \\
\hline 5 & 11.94 & 21.589 & 22.89 \\
\hline 4 & 10.00 & 20.88 & 22.77 \\
\hline 3 & 7.778 & 19.44 & 22.50 \\
\hline 2 & 3.889 & 16.389 & 21.38 \\
\hline 1.5 & 0.2778 & 12.77 & 18.89 \\
\hline 1.25 & & 10.00 & 16.38 \\
\hline 0.6 & & & 7.50 \\
\hline
\end{tabular}

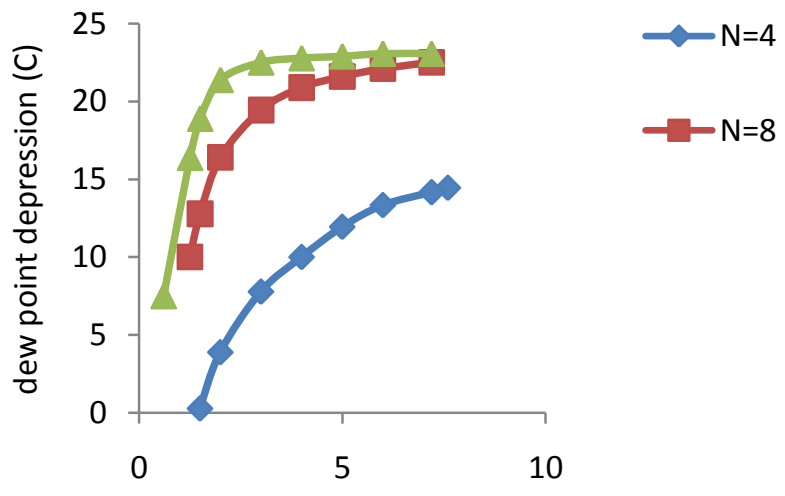

TEG circulation rate (gas/lb-water)

Fig 2 Effects of the number of contactor trays on the dew point depression of natural gas with reboiler temperature $200^{\circ} \mathrm{C}$

Table 3 Overhead water content using a Fixed number of contactor trays at different rebioler temperature (4 trays)

\begin{tabular}{|l|l|l|l|}
\hline & & $\begin{array}{l}\text { Outlet gas } \\
\text { water content } \\
(\mathrm{lb} / \mathrm{mmscf})\end{array}$ & \\
\hline $\begin{array}{l}\text { TEG } \\
\text { rate(gal/lb } \\
\text { water) }\end{array}$ & $\begin{array}{l}\text { Treb } \\
=180^{\circ} \mathrm{C}\end{array}$ & Treb $=190^{\circ} \mathrm{C}$ & Treb $=200^{\circ} \mathrm{C}$ \\
\hline 7.6 & 11.8 & 10 & 9 \\
\hline 7 & 12 & 10 & 9.2 \\
\hline 6 & 12.7 & 11 & 10.2 \\
\hline 5 & 14 & 12 & 11.1 \\
\hline 4 & 15.7 & 14 & 12.8 \\
\hline
\end{tabular}




\begin{tabular}{|l|l|l|l|}
\hline 3 & 17.8 & 16 & 15 \\
\hline 2 & 21.5 & 20 & 19 \\
\hline 1.5 & 25 & 24 & 23.6 \\
\hline
\end{tabular}

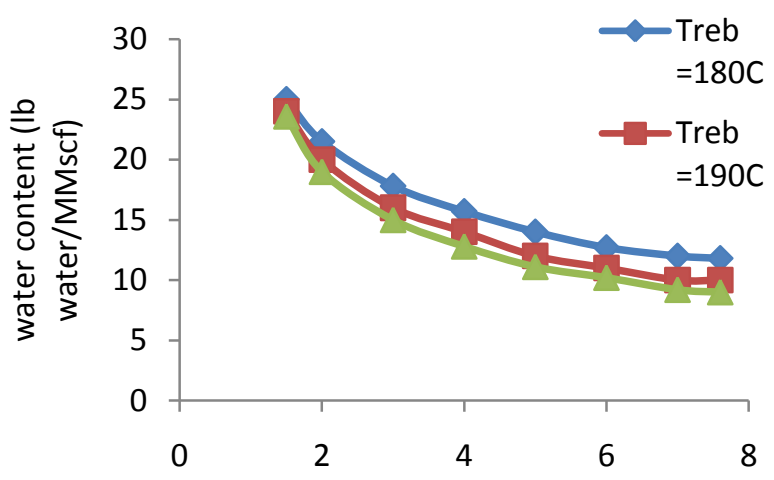

TEG circulation rate (gal/lb-water)

Fig 3 Water content of a natural gas stream heated by a 4tray contactor

Table 4 Overhead water content using a Fixed number of contactor trays at different rebioler temperature (8 trays)

\begin{tabular}{|l|l|l|l|}
\hline & \multicolumn{3}{|c|}{ Outlet gas water content $(\mathrm{lb} / \mathrm{mmscf})$} \\
\hline $\begin{array}{l}\text { TEG } \\
\text { rate(gal/lb } \\
\text { water) }\end{array}$ & $\begin{array}{l}\text { Treb } \\
=180^{\circ} \mathrm{C}\end{array}$ & Treb $=190^{\circ} \mathrm{C}$ & $\begin{array}{l}\text { Treb }= \\
200^{\circ} \mathrm{C}\end{array}$ \\
\hline 7.8 & 8.2 & & \\
\hline 7.5 & 8.22 & 6.8 & \\
\hline 7.2 & 8.3 & 6.82 & 5.35 \\
\hline 6.0 & 8.5 & 6.95 & 5.5 \\
\hline 5.0 & 8.8 & 7.0 & 5.65 \\
\hline 4.0 & 9.0 & 7.4 & 6.0 \\
\hline 3.0 & 9.8 & 8.0 & 6.85 \\
\hline 2.0 & 11.5 & 9.5 & 8.45 \\
\hline 1.2 & 14.8 & 13.4 & 12 \\
\hline
\end{tabular}

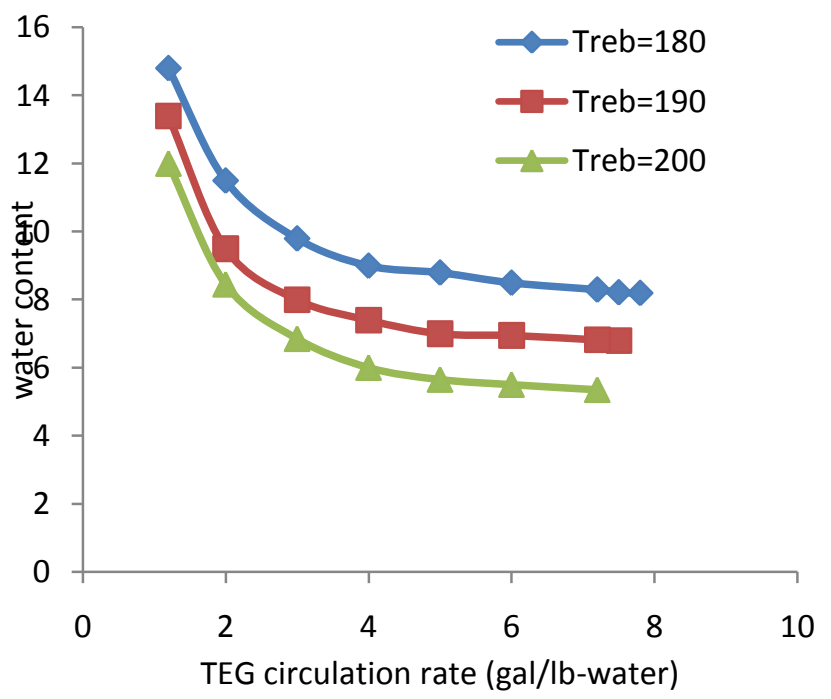

Fig 4 Water content of a natural gas stream heated by a 8tray contactor
Table 5 Overhead water content using a Fixed number of contactor trays at different rebioler temperature (12 trays)

\begin{tabular}{|l|l|l|l|}
\hline & \multicolumn{3}{|l|}{ Outlet gas water content(lb/mmscf) } \\
\hline $\begin{array}{l}\text { TEG } \\
\text { rate(gal/lb } \\
\text { water) }\end{array}$ & $\begin{array}{l}\text { Treb } \\
=180^{\circ} \mathrm{C}\end{array}$ & $\begin{array}{l}\text { Treb } \\
=190^{\circ} \mathrm{C}\end{array}$ & $\begin{array}{l}\text { Treb= } \\
200^{\circ} \mathrm{C}\end{array}$ \\
\hline 7.8 & 8.0 & 6.2 & \\
\hline 7.4 & 8 & 6.2 & 5.0 \\
\hline 7.2 & 8 & 6.25 & 5.0 \\
\hline 6 & 8 & 6.25 & 5.0 \\
\hline 5 & 8 & 6.4 & 5.1 \\
\hline 4 & 8.15 & 6.52 & 5.25 \\
\hline 3 & 8.3 & 7.1 & 5.7 \\
\hline 2 & 8.89 & 7.6 & 6.7 \\
\hline 1.6 & 9.5 & &
\end{tabular}

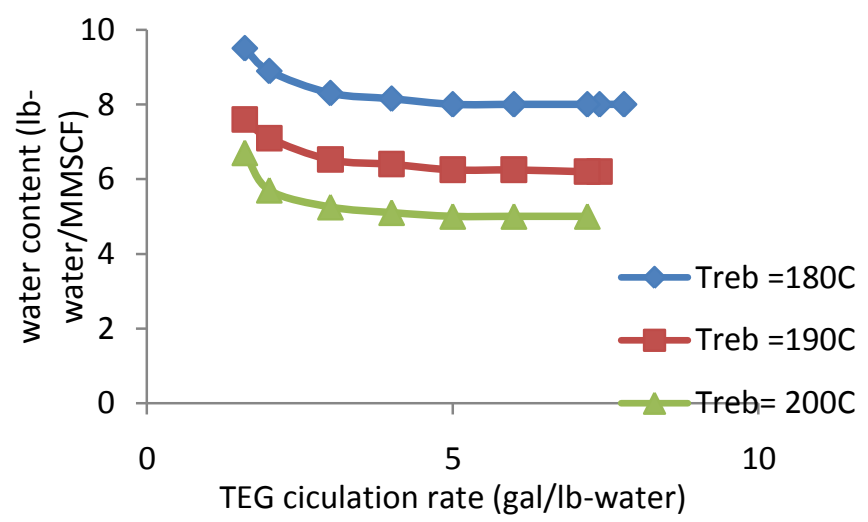

Fig 5 Water content of a natural gas stream heated by a 12tray contactor

Table 6 Deduced values showing the effects of stripping gas rate on water content and glycol circulation rate

\begin{tabular}{|c|c|c|c|c|}
\hline & \multicolumn{4}{|c|}{ Outlet gas water content $(\mathrm{kg} / \mathrm{h})$} \\
\hline $\begin{array}{l}\text { TEG } \\
\operatorname{rate}(\mathrm{gal} / \mathrm{mmscf})\end{array}$ & 0scf/gal & 1scf/gal & 3scf/gal & 6scf/gal \\
\hline 6.6 & 5.35 & 2.1 & 1.4 & 0.9 \\
\hline 6 & 5.4 & 2.2 & 1.5 & 1 \\
\hline 5 & 5.5 & 2.5 & 1.7 & 1.1 \\
\hline 4 & 6 & 3.0 & 2 & 1.5 \\
\hline 3 & 6.8 & 4 & 2.8 & 2.2 \\
\hline 2 & 8.5 & 5.5 & 4.7 & 4.5 \\
\hline 1.2 & 13.0 & 10.5 & 9 & 9 \\
\hline 1 & & 12.4 & 11 & 11 \\
\hline
\end{tabular}




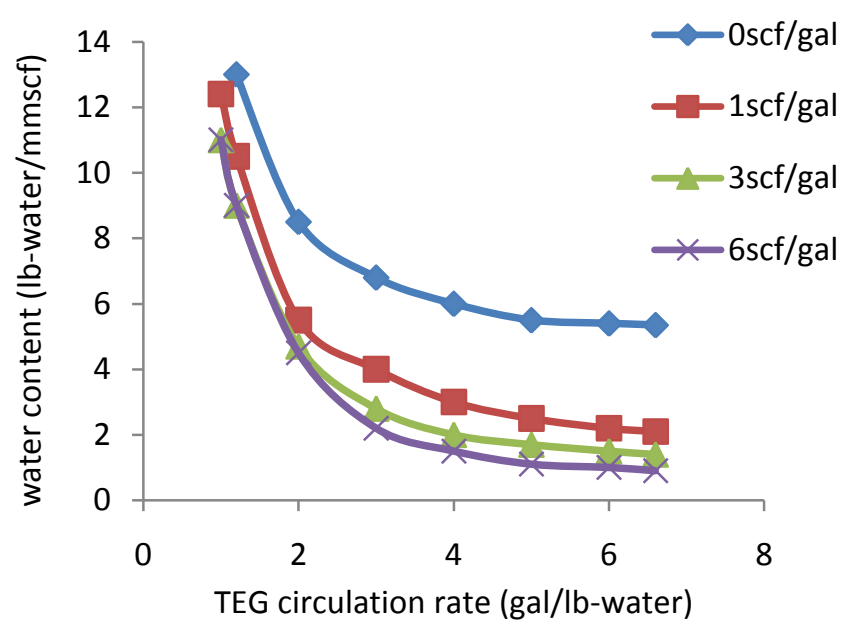

Fig 6 Effects of stripping gas rate on water content of natural gas streams

Table 7 Relationship between dew point depression and stripping gas rate

\begin{tabular}{|l|l|}
\hline $\begin{array}{l}\text { Stripping gas rate } \\
(\mathrm{gal} / \mathrm{mmscf})\end{array}$ & Dew point depression $\left({ }^{\circ} \mathrm{C}\right)$ \\
\hline 6 & 32 \\
\hline 3.2 & 30 \\
\hline 1 & 26 \\
\hline 0 & 18 \\
\hline
\end{tabular}

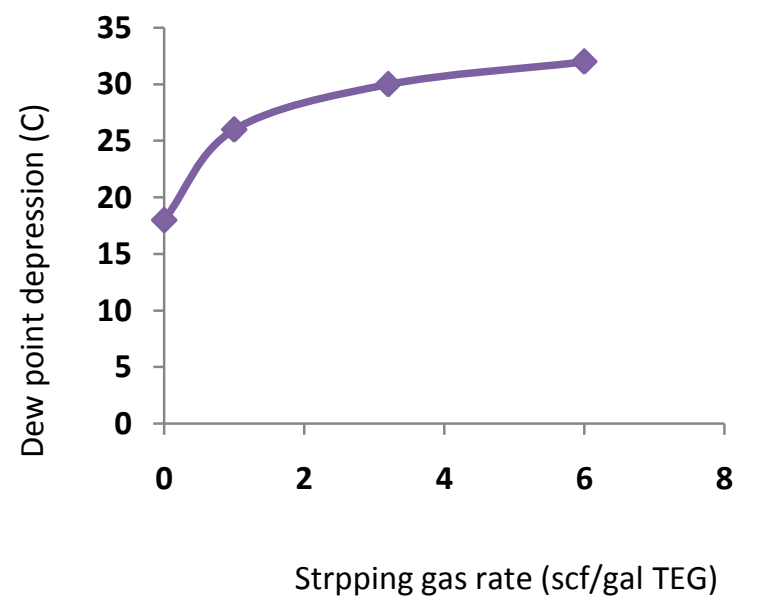

Fig 7 Effects of stripping gas on dew point depression

\section{CONCLUSIONS}

The design review involved a review of the TEG dehydration systems generally and in comparison to the proposed design, the Niger Delta plant is adequate and robust enough to condition the gas to comfortably achieve a water dew point of $5^{\circ} \mathrm{C}$ at $95 \mathrm{bar}$. It is highly recommended that regular inspection of glycol contactor internals are conducted at intervals so as to check components of the system if they are in good condition and still operates properly. Also regular dew point measurements and validation from the moisture analyzers installed on the gas processing trains will be a lot easier with reverse calculations using HYSYS. Operational review process involved spot checks of key process parameters in the TEG dehydration systems and plant is operated in a satisfactory manner within the design envelop.

\section{NOMENCLATURE}

TEG Triethylene Glycol

GTS Gas Transport Systems

HPLT High Pressure Low Temperature

LPHT Low Pressure High Temperature

Treb reboiler Temperature

\section{ACKNOWLEDGEMENTS}

The author highly appreciates the insurmountable efforts of Daniel Dasigha Pepple and Ohazuruike V. Lotanna in the fruitiness of this Study. Among other Such as Family, Friends and colleagues highly recognized.

\section{REFERENCES}

[1]. Arnold, K and Stewart, M. "Surface Production Operations", Vol 2, Design of Gas Handling Systems and Facilities, 1999.

[2]. Lyons, W. C.: "Standard Handbook of Petroleum and Natural Gas Engineering”, Vol. 3, 1994

[3]. Katz D.L "Handbook of Natural Gas Engineering, Production and Storage ", McGraw-Hill Book Co., Inc 1990.

[4]. Hernandez, V., Hainvinka, M. W. and Bullin, J. A.: "Designing Glycol Units For Maximum Efficiency". Bryan Research and Engineering, Inc. 2001

[5]. Campbell, J. M.: "Gas Conditioning and Processing" Vol 2, Campbell and Company 2001.

[6]. McLeod, W.R : Prediction and control of natural gas pipeline. SPE8137 presented at the European offshore petroleum conference and exhibition in London 24-27 October, 1978, pp.1-8

[7]. Rossi, L.F. and Gas paretto, C. A .1991 "Prediction of hydrate formation in natural gas system, paper SPE 22715 presented at the 66th Annual Technical Conference exhibition of the SPE held in Dallas, TX ,October 69,1991.pp. 1-7..

[8]. Sloan, E.D. “ Natural gas hydrate”, SPE 23562, Journal of Petroleum Technology, 1991. pp 1-4.

[9]. Ikoku, C. U" Natural gas Engineering" Pennwell Publishing Company, Tulsa, Oklahoma 1980

[10]. Bhangole, A. Y., Zhu, T., Mc Grail, B. P. and White, M. D. 2006 "A model to predict gas hydrate equilibrium and gas hydrate in the process media including mixed CO2 CH4 Hydrates", paper SPE 99759 paper presented at the 2006 SPE/DOE symposium on improved oil recovery held in Tulsa, Oklahoma,22-26,April 2006, Pp. 1-7. 